\title{
The role of motivation in MOOCs' retention rates: a systematic literature review
}

\author{
Mehdi Badali ${ }^{1 *} \mathbb{D}$, Javad Hatami ${ }^{1}$, Seyyed Kazem Banihashem² ${ }^{2}$ Ebrahim Rahimi ${ }^{3}$, Omid Noroozi ${ }^{2}$ and \\ Zahra Eslami ${ }^{4}$
}

\section{*Correspondence:}

badali.tech@gmail.com

${ }^{1}$ Department of Education,

Faculty of Humanities, Tarbiat Modares University, Tehran, Iran

Full list of author information is available at the end of the article

\begin{abstract}
Although MOOCs platforms offer a unique way to provide information for a large cohort of participants, only a small percentage of participants complete MOOCs. The high number of dropouts in MOOCs is a key challenge, and the literature suggests that it can be affected by participants' motivation. However, it is not known how and to what extent motivation influences participants' dropout in MOOCs. There is a need to provide an overview of the role of motivation in MOOCs'retention. In this study, we aimed to identify motivational factors and theories that affect participants' retention in MOOCs and explain how does motivation supports participants to complete MOOCs. To do so, a systematic review was conducted using specific inclusion and exclusion criteria and a set of relevant keywords and databases which resulted in 50 relevant publications. Our analysis led us to identify six main motivational factors that influence participants' $\mathrm{MOOC}$ s completion including academic, social, course, personal, professional, and technological motives. These factors were divided into two main categories including need-based motivation and interest-based motivation. The results showed that academic motives play the most important role in participants' MOOCs retention compared to the other factors. It was also found that self-determination theory was used as the most dominant theory to support participants' motivation for MOOCs completion. In addition, the results revealed that the motivational factors not only impacts participants' $\mathrm{MOOC}$ retention directly, but also this impact is mediated by participant satisfaction, self-regulation, attitude toward using MOOCs, performance, engagement, and level of participation. Based on the results, further implications for practice and future research are provided.
\end{abstract}

Keywords: MOOCs dropout, MOOCs retention, MOOCs completion, Motivation, Systematic review

\section{Introduction}

Over the past few years, the use of digital technologies to provide ubiquitous education increased in popularity (Lizcano et al., 2020). MOOCs have the potential to provide learners with the opportunity to access global education and lifelong learning (Badali et al., 2020). MOOCs are considered popular learning platforms (Welsh \& Dragusin, 2013), and over the past years, millions of the Internet users have taken online classes offered by MOOC platforms (Nurhudatiana \& Caesarion, 2020). Despite the high

c) The Author(s) 2022. Open Access This article is licensed under a Creative Commons Attribution 4.0 International License, which permits use, sharing, adaptation, distribution and reproduction in any medium or format, as long as you give appropriate credit to the original author(s) and the source, provide a link to the Creative Commons licence, and indicate if changes were made. The images or other third party material in this article are included in the article's Creative Commons licence, unless indicated otherwise in a credit line to the material. If material is not included in the article's Creative Commons licence and your intended use is not permitted by statutory regulation or exceeds the permitted use, you will need to obtain permission directly from the copyright holder. To view a copy of this licence, visit http:// creativecommons.org/licenses/by/4.0/. 
number of enrollment in MOOCs, over 90\% of enrollees never finish the course (Eriksson et al., 2017; Narayanasamy \& Elçi, 2020). MOOCs' retention rate ranges between 3 and 15\% (Deshpande \& Chukhlomin, 2017; Jordan, 2014; Liyanagunawardena et al., 2013). From 2016 onwards, the issue of high attrition and dropout rates in MOOCs has become a research trend in online education (Zhu et al., 2018). Dalipi et al. (2018) found that two main factors predict learner dropout in MOOCs, learner-related factors (e.g., lack of motivation, lack of time, insufficient background knowledge and skills) and MOOC-related factors (e.g., course design, feelings of isolation and the lack of interactivity, hidden cost). Goopio and Cheung (2020) in a systematic review study reported that various factors such as vague course design, lack of interaction, learner experience, time management, and mastery of MOOCs course language affect persistence in MOOCs' programs.

High dropout rates in MOOCs have raised questions in terms of MOOC effectiveness (Alraimi et al., 2015; Xing \& Du, 2019) and are a cause of concern for education scientists (Aldowah et al., 2020). Various studies have been conducted to find out reasons and strategies for reducing attrition and dropout rates in MOOCs (e.g., Dalipi et al, 2018; Goopio \& Cheung, 2020; Kim et al., 2017). The literature review suggests that motivation is one of the main factors that can impact learners' retention in MOOCs (Maya-Jariego et al., 2020; Abdullatif \& Velázquez-Iturbide, 2020; Tang \& Chaw, 2019; Watted \& Barak, 2018; Verbert et al., 2012). Maya-Jariego et al. (2020) categorized MOOC participants into three groups of internal motives, external motives, and intention of persistence. They then reported that intensity of motivation is positively related to MOOC retention and satisfaction. Abdullatif and Velázquez-Iturbide (2020) pointed out that motivation has a key role to play in explaining learners' behavior in MOOCs and reported that internal motivation strongly affects intention to continue with MOOCs. The results of a study by Tang and Chaw (2019) also confirmed that there is a significant relationship between participants' motivation and course completion in MOOCs.

Despite the role of motivation in MOOC dropout rates, it is still unclear what types of motivational factors stimulate learners to finish MOOCs (Deshpande \& Chukhlomin, 2017). Previous research concentrated on a certain type of motivation concerning MOOCs' dropout (e.g., Abdullatif \& Velázquez-Iturbide, 2020; Watted \& Barak, 2018; Bonk \& Lee, 2017; Maya-Jariego et al., 2020; Watted \& Barak, 2018). A review of research in the field of MOOC reported that most studies in this field have been done quantitatively (Zhu et al, 2020). Scholars have pointed out that there is a need for a comprehensive overview of the role of motivation in MOOC dropout rates (Wang \& Baker, 2018). In this systematic review, we aim to highlight motivational factors and theories impacting learner retention rates in MOOCs and how these factors could support learners to complete their courses. The results of this study shed light on the weightings of motivational factors intended to support course completion in MOOCs. The following research questions are formulated to address the main objectives of the study.

RQ1. What motivational factors affect participants' retention in MOOCs? RQ2. What theories support participants' motivation to complete MOOCs?

RQ3. To what extent does motivation support participants' course completion in MOOCs? 


\section{Methods}

Lockwood and Oh (2017) suggested seven steps for systematic review: (1) developing a structured question(s), (2) defining inclusion and exclusion criteria, (3) developing a search strategy, (4) critical appraisal, (5) data extraction, (6) analysis of extracted data, and (7) presentation of the findings. These steps were followed in this study. The selection process of reviewed publications is presented in Fig. 1.

\section{Inclusion and exclusion criteria}

Several inclusion and exclusion criteria were followed in this systematic review. First, only peer-reviewed articles written in English were included since the authors could not understand other languages. Second, the period was limited to publications from 2015 to 2020 to include the most recent publications. Third, there were no restrictions with regard to research settings or population, and all types of research including quantitative, qualitative, and mixed studies were welcomed in this study. Forth, researchers decided to exclude review papers, reports, interviews, and other kinds of documents such as thesis, dissertations, conference proceedings, books and book chapters, and also published articles that were not peer-reviewed. Fifth, studies with poor and unclear findings were excluded since they did not provide sound

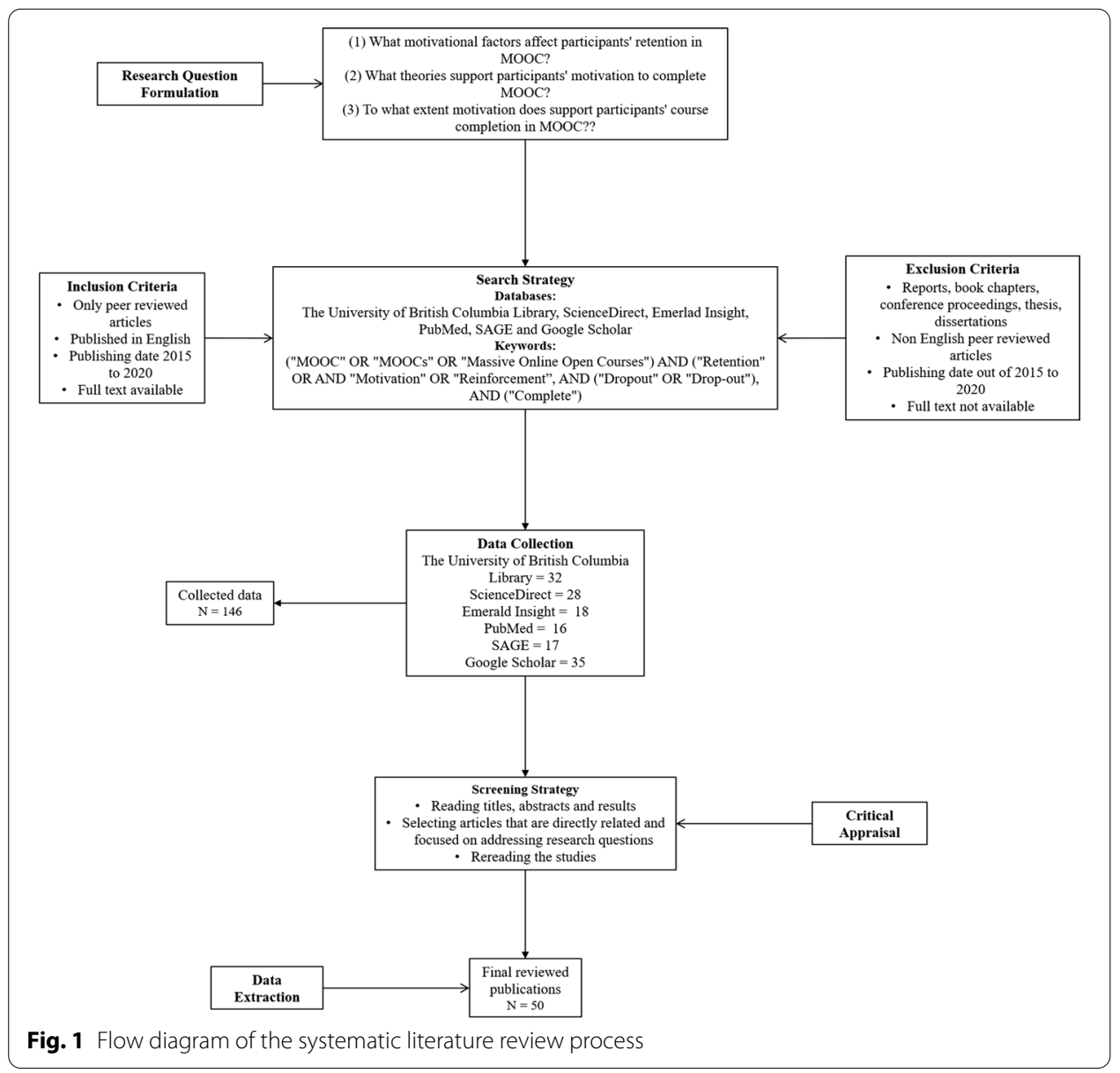


information addressing the research questions. Sixth, the availability of only full-text papers was included in this study.

\section{Search strategy}

To develop the search strategy, in the first step, keywords and relevant synonyms were identified and used as follows: ("MOOC" OR "MOOCs" OR "Massive Online Open Courses") AND ("Retention" OR "Motivation" OR "Reinforcement") AND ("Dropout" OR "Drop-out") AND ("Complete"). The Boolean operators were used to increase the search precision. In the second step, researchers determined which databases should be screened. For this purpose, the University of British Columbia Library, ScienceDirect, Emerald Insight, PubMed, SAGE, and Google Scholar were used.

\section{Critical appraisal}

As a first step, researchers $(N=2)$ who both had educational technology background (Coder 1 is a Postdoctoral Researcher in Education and Learning Sciences, he also has several articles in the field of learning analytic and systematic review, and coder 2 is a $\mathrm{Ph}$.D. of educational technology with experience in data analysis, he also has several articles in the field of MOOCs) screened selected papers to remove duplications and exclude papers that fell outside the scope of this review. To critically appraise the selected studies, three criteria were determined: (1) for each study, a binary category (relevant/not relevant) was used after reading the title and abstract; (2) only studies with clear findings, implications, and evidence related to the research questions were included; (3) papers with software, programming, and technical levels were excluded and just papers with educational implications were included. Critical appraisal was followed in two rounds. In the first round, researchers critically screened selected papers based on the aforementioned criteria. In this phase, 57 papers out of 146 papers were selected. In the second round, researchers decided to critically review selected papers for a second time and read the whole paper to make sure that only relevant studies were included for data extraction. In this phase, 11 papers were excluded since researchers did not find them strongly relevant for this study. At the end of the second critical review, only 46 papers were found to be relevant to the objectives of this study. During critical reading, researchers were confronted with studies that were mentioned in included publications. Researchers decided to screen these papers for relevance, resulting in 4 additional papers being added to the total amount of studies investigated. Finally, 50 publications were selected for analysis. When the critical appraisal phase was completed, the other two researchers were asked to screen and code the studies based on the explained inclusion and exclusion criteria to reduce the bias in the search. These researchers also read the title and abstract of each study and assessed studies in a binary manner to be relevant/not relevant. In cases where study findings were not obvious from the abstract section, researchers were instructed to read the papers thoroughly (for example, they read the methods and/or results in sections). Findings of the screening and coding showed that changes between the original screening and the second review were minor. To reduce the bias selection process and interpretation, the inter-rater reliability agreement between the two coders was performed which, the kappa coefficient was $76 \%$ that 
indicates a high agreement of the researchers. The final set included 50 publications that met all inclusion criteria.

\section{Data extraction}

In this study, 50 scientific publications were finally reviewed. The review of included publications showed that most publications (about 42\%) were published in the Journal of Computers \& Education, Journal of Computers in Human Behavior, and British Journal of Educational Technology. The geographical distribution of publications based on country of origin of the corresponding author was as follows: authors from the USA (26\%, $N=13)$, authors from China $(14 \%, N=7)$, authors from Spain $(10 \%, N=5)$, authors from Mexico, the UK, Australia, South Korea, and Taiwan (each 6\%, N=3). Authors from other countries included $20 \%(N=10)$. The details of selected studies are presented in Table 1 and Fig. 2.

As can be seen in Fig. 2, quantitative research methods were used in the majority of reviewed publications $(64 \%, N=32)$, whereas only $16 \%$ of studies $(N=8)$ used qualitative methods and $20 \%$ of studies $(N=10)$ used mixed research methods. The most popular MOOCs' platforms in reviewed publications were Coursera (about $31 \%, N=18$ ), edX (about 22\%, $N=13$ ), and iCourse (about 9\%, $N=5$ ), respectively. Structural Equation Modeling (SEM), content analysis, factor analysis, Partial Least Squares (PLS), descriptive, ANCOVA/ ANOVA/ MANOVA, t-test, survival analysis, and regression were, respectively, used in reviewed publications as common statistical tools. Generally, interview $(18 \%, N=9)$, survey $(70 \%, N=35)$, and interview/survey $(12 \%, N=6)$ were used as data collections tools in reviewed publications.

\section{Analysis of extracted data}

To address the first research question, it was, first, decided to review findings of all included publications to extract which motivational factors affected participants' retention in MOOCs. Second, extracted motivational factors were categorized under an umbrella of a larger concept. To address the second research question, all included publications were reviewed to identify which motivational theories were used to support participants' motivation to complete MOOCs. The frequency of theory usage in selected papers was then counted, and an overview of the most commonly used motivational theory was provided. To address the third research question, findings of all included papers were reviewed and a concept map of how motivation supports participant course completion in MOOCs was presented.

\section{Results}

\section{Research Question 1}

What motivational factors affect participants' retention in MOOCs? The findings of Research Question 1 were divided into two motivational sources namely need-based (Green et al, 2017) and interest-based (Shen et al, 2003). Categories related to needbased motivation are academic motives, course motives, and professional motives. Categories related to interest are social motives, personal motives, and technological motives. Table 2 gives detailed information concerning these motivational factors. According to Table 2, column $N$ represents the sum of frequencies and column Pct. 
Table 1 Characteristics of the selected studies

\begin{tabular}{|c|c|c|c|}
\hline Authors & Year & Journal & $\begin{array}{l}\text { Country } \\
\text { (correspond } \\
\text { author) }\end{array}$ \\
\hline Abdullatif et al. & 2020 & Education and Information Technologies & Spain \\
\hline Aldowah et al. & 2020 & Journal of Computing in Higher Education & UK \\
\hline Espinosa et al. & 2015 & $\begin{array}{l}\text { International Journal of Educational Technology in } \\
\text { Higher Education }\end{array}$ & Mexico \\
\hline Bayeck & 2016 & Open Praxis & USA \\
\hline Alario-Hoyos et al. & 2017 & $\begin{array}{l}\text { The International Review of Research in Open and } \\
\text { Distributed Learning }\end{array}$ & Spain \\
\hline Wang and Baker & 2018 & $\begin{array}{l}\text { The International Review of Research in Open and } \\
\text { Distributed Learning }\end{array}$ & USA \\
\hline Alraimi et al. & 2015 & Computers and Education & USA \\
\hline Barak et al. & 2016 & Computers and Education & Israel \\
\hline Buhr et al. & 2019 & Computers in Human Behavior & Canada \\
\hline Deshpande and Chukhlomin & 2017 & American Journal of Distance Education & USA \\
\hline Doo et al. & 2020 & Distance Education & USA \\
\hline Bonk and Lee & 2017 & Journal of Learning for Development & USA \\
\hline Tang and Chaw & 2019 & Electronic Journal of e-Learning & Malaysia \\
\hline Eriksson et al. & 2017 & Journal of Computing in Higher Education & Sweden \\
\hline Gregori et al. & 2018 & Computers and Education & China \\
\hline Hone and El Said & 2016 & Computers and Education & UK \\
\hline Howarth et al. & 2016 & International Journal of Lifelong Education & Australia \\
\hline Jung and Lee & 2018 & Computers and Education & South Korea \\
\hline Khan et al. & 2018 & Telematics and Informatics & China \\
\hline Kim et al. & 2017 & Computers in Human Behavior & South Korea \\
\hline Kyewski and Krämer & 2018 & Computers and Education & Germany \\
\hline Li et al. & 2018 & Computers in Human Behavior & Singapore \\
\hline Luik et al. & 2019 & British Journal of Educational Technology & Estonia \\
\hline Maya-Jariego et al. & 2020 & Educational Technology Research and Development & Spain \\
\hline Ortega-Arranz et al. & 2019 & Computers and Education & Spain \\
\hline Gomez-Zermeno et al. & 2016 & Turkish Online Journal of Distance Education & Mexico \\
\hline Salmon et al. & 2017 & British Journal of Educational Technology & Australia \\
\hline Shao & 2018 & Internet Research & China \\
\hline Shapiro et al. & 2017 & Computers and Education & USA \\
\hline Carrera and Ramírez-Hernández & 2018 & Sustainability & Mexico \\
\hline Tsai et al. & 2018 & Computers and Education & Taiwan \\
\hline Uchidiuno et al. & 2018 & $\begin{array}{l}\text { International Journal of Artificial Intelligence in Educa- } \\
\text { tion }\end{array}$ & USA \\
\hline Wang et al. & 2019 & Behavior and Information Technology & Taiwan \\
\hline Wang and Baker & 2015 & Journal of Online Learning and Teaching & USA \\
\hline Watted and Barak & 2018 & The Internet and Higher Education & Israel \\
\hline Wu and Chen & 2017 & Computers in Human Behavior & China \\
\hline Xing et al. & 2019 & The Internet and Higher Education & USA \\
\hline Zhang & 2016 & Computers and Education & China \\
\hline Zhao et al. & 2020 & Computers and Education & China \\
\hline Xiong et al. & 2015 & Global Education Review & USA \\
\hline Petronzi and Hadi & 2016 & European Journal of Open, Distance and E-learning & UK \\
\hline Sujatha and Kavitha & 2018 & $\begin{array}{l}\text { International Journal of Education and Development } \\
\text { Using ICT }\end{array}$ & India \\
\hline Brooker et al. & 2018 & Australasian Journal of Educational Technology & Australia \\
\hline El Said & 2017 & Journal of Educational Computing Research & Egypt \\
\hline
\end{tabular}


Table 1 (continued)

\begin{tabular}{llll}
\hline Authors & Year & Journal & $\begin{array}{l}\text { Country } \\
\text { (correspond } \\
\text { author) }\end{array}$ \\
\hline $\begin{array}{lll}\text { Greene et al. } \\
\text { James }\end{array}$ & 2015 & American Educational Research Journal & USA \\
& 2020 & Journal of College Student Retention: Research, Theory & USA \\
Charo et al. & 2020 & Computers in Human Behavior & Spain \\
Chang et al. & 2015 & British Journal of Educational Technology & Taiwan \\
Joo et al. & 2018 & Computers and Education & South Korea \\
Sun et al. & 2019 & British Journal of Educational Technology & China \\
\hline
\end{tabular}

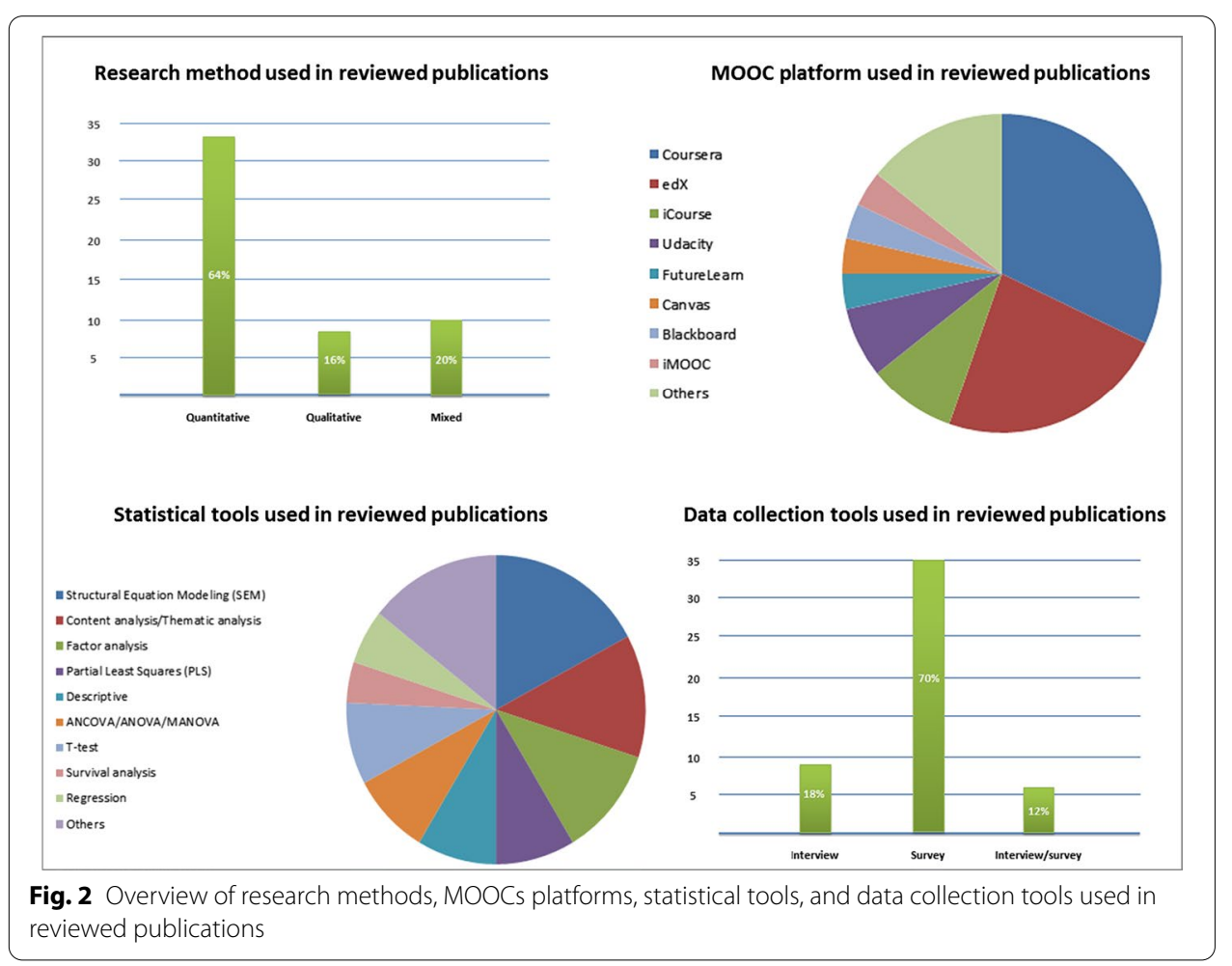

shows the sum of the percentage of frequencies for each motivational category in the reviewed publications.

Based on scanning data of included publications presented in Table 2, academic motives had the largest role and were the most frequently used motivational factor for MOOCs' retention (about 30\%, $N=71$ ). Social motives (about 19\%, $N=45$ ) were the second most popular factor to encourage participants to complete MOOCs, followed by course motives (about 16\%, $N=38$ ), personal motives (about 15\%, $N=37$ ), professional motives (about 13\%, $N=30$ ), and technological motives (about $8 \%, N=19$ ). The following motivational source and related motivational categories were described.

Need-based motivation: The purpose of need-based motivations to register or complete a MOOC is to bridge the knowledge, skill, or attitude gap in the individual. 
Table 2 Detailed information concerning the main motivational factors

\begin{tabular}{|c|c|c|c|c|}
\hline Motivational source & Category & Motivational factor & $N$ & Pct \\
\hline \multirow[t]{3}{*}{ Need-based } & Academic motives & $\begin{array}{l}\text { To earn credit course from professors, to earn } \\
\text { credit course from institutes, intrinsic goal } \\
\text { orientation, academic self-efficacy, need for } \\
\text { cognition, grit (passion for long-term goals), } \\
\text { performance-goal orientation, mastery-goal } \\
\text { orientation, perceived reputation, complemen- } \\
\text { tary learning, learning support, self-assessment, } \\
\text { self-improvement, freedom to learn, English } \\
\text { proficiency, achievement motivation, learning } \\
\text { outcome, further existing knowledge, improving } \\
\text { knowledge, previous bad classroom experiences } \\
\text { with the subject matter, using innovative tools } \\
\text { (flipped classroom, challenge-based, earning), } \\
\text { query-based learning, certification, value learn- } \\
\text { ing, gamification, supplement to a university } \\
\text { class, learning design, study techniques, teaching } \\
\text { presence, teacher presence, discouragement } \\
\text { based on faulty assignment }\end{array}$ & 71 & $29.58 \%$ \\
\hline & Course motives & $\begin{array}{l}\text { Time (course length), course difficulty, course } \\
\text { structure, course content, perception of course } \\
\text { design, course related to the program, percep- } \\
\text { tion of the course content, expectations about } \\
\text { course and suitability of course, perceived effec- } \\
\text { tiveness, perceived quality, task value and inter- } \\
\text { est, overload (heavy load of study), learner social } \\
\text { situation, novelty, lack of control, autonomy, } \\
\text { sense of scarcity, high-quality course materials }\end{array}$ & 38 & $15.83 \%$ \\
\hline & Professional motives & $\begin{array}{l}\text { Professional development, work circumstances, } \\
\text { course related to the job, acquire skills, perceived } \\
\text { usefulness, relevancy to job, fulfillment of need } \\
\text { for competence, problem-solving, economic } \\
\text { mobility, statement of accomplishment }\end{array}$ & 30 & $12.50 \%$ \\
\hline \multirow[t]{4}{*}{ Interest-based } & Personal motives & $\begin{array}{l}\text { Internal motives, family circumstances, curiosity, } \\
\text { personal growth, personal interest, self-enjoy- } \\
\text { ment, liking, perceived enjoyment, boredom, } \\
\text { self-development, self-determination, perceived } \\
\text { value, user preference, prior knowledge, and } \\
\text { experience }\end{array}$ & 37 & $15.41 \%$ \\
\hline & Social motives & $\begin{array}{l}\text { Social support, interaction, friends taking a } \\
\text { course, social presence, connect with others, net- } \\
\text { working, meet new people, social situation, social } \\
\text { influences, social norms, communication and } \\
\text { use of information, social mobility, relatedness, } \\
\text { learner social characteristics, rewards, badges, } \\
\text { social recognition }\end{array}$ & 45 & $18.76 \%$ \\
\hline & Technological motives & $\begin{array}{l}\text { Perceived ease of use, perceived openness, navi- } \\
\text { gation, accessibility, visual design, the frustration } \\
\text { of MOOCs, Internet access, media richness, socia- } \\
\text { bility, convenience, interactive design, integrative } \\
\text { design, limiting repeatability of online courses, } \\
\text { lack of infrastructures, multimedia use }\end{array}$ & 19 & $7.91 \%$ \\
\hline & Total & & 240 & $100 \%$ \\
\hline
\end{tabular}

According to need-based motivation, learners voluntarily learn to obviate their educational needs. Need-based theories say that behavior is partly motivated by external factors, but even more (Ahl, 2008). Need-based motivations include: academic, course, and professional motives.

Academic motives: Academic motivation is a broad term used for students' desire in terms of academic subjects. This type of motivation explains that students with high 
academic motivations tend to achieve more academic success (Zimmerman, 2008), while students with low academic motivations experience more academic failure (Scheel et al., 2009). Review of MOOC related literature confirmed that academic selfefficacy (Jung \& Lee, 2018; Shao, 2018; Wang \& Baker, 2018), teaching presence (Jung \& Lee, 2018), using innovative teaching tools such as gamification, flipped classroom, query-based learning (Carrera \& Ramírez-Hernández, 2018; Chang et al., 2015; Eriksson et al., 2017; Ortega-Arranz et al., 2019), achieving further knowledge and learning skills (Watted \& Barak, 2018; Salmon et al., 2017; Petronzi \& Hadi, 2016), receiving a certification (Charo et al., 2020; Greene et al., 2015; Uchidiuno et al., 2018; Wang \& Baker, 2018; Watted \& Barak, 2018; Xiong et al., 2015), and earn credit (Bayeck, 2016) are some of the academic motives that influence MOOCs retention.

Course motives: This type of motivation refers to the potential of course structure, design, and content to attract learners to decide whether to take and complete MOOCs or not. James' (2020) research showed that the complexity and difficulty of course content impacts participants' dropout in MOOCs. Kizilcec and Halawa (2015) highlighted the importance of course timing as one of the reasons to finish or drop MOOCs. Their study showed that a course longer lasts, there are more chances for dropout. In another study, Charo et al. (2020) pointed out that the perceived effectiveness of the course is significantly related to MOOCs retention. In other words, learners should find course content effective to follow up with it. This finding is supported by Alario-Hoyos et al. (2017) where they found task value as a meaningful variable for MOOCs retention. In addition, other studies emphasized the role of course design as another important factor that influences participants' dropout in MOOCs (Aldowah et al., 2020; Eriksson et al., 2017; El Said, 2017).

Professional motives: MOOCs are an opportunity to acquire new knowledge, skills and expand occupational development (Milligan \& Littlejohn, 2017). Professional motives refer to professional development and career reasons why participants use MOOCs and intend to complete them. A review of the literature confirmed that needs for professional development are highly motivative for MOOCs users (Bayeck, 2016; Doo et al., 2020; Xiong et al., 2015). Previous studies indicated that some people use MOOCS because it is related to their job and profession (Bayeck, 2016; Xiong et al., 2015). Lu et al. (2017) reported that there is a significant relationship between course relevancy to a job and MOOCs users' satisfaction and depth of learning. Review on the MOOCs literature revealed that work circumstances (Aldowah et al., 2020; Shapiro et al., 2017), workplace knowledge and experience (Greene et al., 2015; Petronzi \& Hadi, 2016), course relevancy to job (Bayeck, 2016; Uchidiuno et al., 2018; Xiong et al., 2015), and economic mobility (Eriksson et al., 2017; Uchidiuno et al., 2018) are some of the professional motives affect learners' MOOCS retention.

Interest-based motivation: Interest is a strong motivator for enrolling and learning from MOOCs (Tsai et al, 2018). Interest-based motivation suggests that interest can be a major motivation source that arises as individuals interact with the environment. According to research evidence, interest is divided into personal and situational interests (Shen et al., 2003). Personal and social motives are related to personal interest, and technological motives are related to situational interest. 
Personal motives: This type of motivation refers to personal reasons why a person takes a MOOC. Findings of previous studies showed that family circumstances (Aldowah et al., 2020), curiosity (Bonk \& Lee, 2017), personal growth (Watted \& Barak, 2018), enjoyment and boredom (Buhr et al., 2019; Shao, 2018), personal interest Watted \& Barak, 2018; Chang et al., 2015), personal reasons (Petronzi \& Hadi, 2016), and prior experiences (Greene et al., 2015) are some of the reasons can personally motivate or demotivate participants whether to drop out MOOCs or finish it. Considering the low impacts of certifications in MOOCs retention (Wang \& Baker, 2015), having personal motives to take a MOOCs tend to play a major role in MOOCs completion (Kizilcec \& Halawa, 2015).

Social motives: Social motives refer to human needs to connect with and be accepted by others. This desire represents ones' social preferences which highly impact social decisions (Godman, 2013; Locke, 2015). A review of MOOC literature showed that social factors such as social presence, social support (Aldowah et al., 2020), interactions (Gregori et al., 2018; Hone \& El Said, 2016), meeting new people (Uchidiuno et al., 2018), friends taking a course, and connection with others (Bayeck, 2016; Xiong et al., 2015) affect MOOCs users' decisions to choose a course and complete it. Social motivations in MOOCs make the course more attractive for learners and improve the level of participation, engagement, performance, and attitude toward using MOOCs which are important factors in MOOCs completion (e.g., Alraimi et al., 2015; Barak et al., 2016; Buhr et al., 2019; Khan et al., 2018; Kyewski \& Krämer, 2018; Tang \& Chaw, 2019).

Technological motives: Technological types of motivation speak about to what extent technology motivates learners to participate in MOOCs and complete it. MOOCs studies highlighted the technological potential to encourage learners to not drop out of MOOCs. For example, studies showed that perceived ease of use of technology (Joo et al., 2018; Jung \& Lee, 2018; Wu \& Chen, 2017), media richness (Zhao et al., 2020), the potential for interactivity (Deshpande \& Chukhlomin, 2017; Zhao et al., 2020), visual design (Deshpande \& Chukhlomin, 2017), lack of infrastructure (Shapiro et al., 2017), accessibility (Khan et al., 2018; Shapiro et al., 2017; Eriksson et al., 2017; Deshpande \& Chukhlomin, 2017; El Said, 2017), and convenience of technology (Shapiro et al., 2017) impact participant's use of MOOCs and also their decisions for dropout or intention to continue using MOOCs.

\section{Research Question 2}

What theories support participants' motivation to complete MOOCs? A review of the included publications showed that a variety of theories were used to theoretically support participants' motivation for course completion in MOOCs. Table 3 presents a list of the main theories used in the reviewed studies to support participants' motivation not to drop out of MOOCs. In the first column, dimensions of theories are given, then motivational theories, and similar to Table 2, column $N$ in Table 3 indicate the sum of frequencies and subsequently column Pct. represents the sum of the percentage of frequencies for each theory is included papers. We followed a bottom-up inductive approach to classifying the theories in the second column based on their essential features and dimensions. This approach led us to discern five classes of theories covering the link between learner's control, engagement/behavioral, learners' motivation and social, technological, 
Table 3 Theories used to support participants' motivation for MOOCs retention

\begin{tabular}{|c|c|c|c|}
\hline Dimensions of theory & Theory & $n(\%)$ & $N(\%)$ \\
\hline \multirow[t]{4}{*}{ Learner's control dimension } & Self-determination theory (SDT) & $15(25)$ & $23(38.33)$ \\
\hline & Psychological reactance theory (PRT) & $3(5)$ & \\
\hline & Self-regulated learning theory (SRLT) & $3(5)$ & \\
\hline & $\begin{array}{l}\text { Control-value theory of achievement emotions } \\
\text { (CVTAE) }\end{array}$ & $2(3.33)$ & \\
\hline \multirow[t]{6}{*}{ Pedagogical dimension } & Expectancy value theory (EVT) & $3(5)$ & $11(18.33)$ \\
\hline & Achievement goal theory (AGT) & $2(3.33)$ & \\
\hline & Expectation Confirmation Theory (ECT) & $3(5)$ & \\
\hline & Constructive learning theory (CLT) & $1(1.16)$ & \\
\hline & Adult learning theory (ALT) & $1(1.16)$ & \\
\hline & Experiential learning theory (ELT) & $1(1.16)$ & \\
\hline \multirow[t]{5}{*}{ Technological dimension } & Technology acceptance model (TAM) & $5(8.33)$ & $10(16.66)$ \\
\hline & Flow theory $(\mathrm{FT})$ & $2(3.33)$ & \\
\hline & Task technology adaptation theory (TTAT) & $1(1.16)$ & \\
\hline & Media-richness theory (MRT) & $1(1.16)$ & \\
\hline & Theory of network externalities (TNE) & $1(1.16)$ & \\
\hline \multirow[t]{4}{*}{ Social dimension } & Connectivism theory $(\mathrm{CT})$ & $3(5)$ & $6(10)$ \\
\hline & Social cognitive theory (SCT) & $1(1.16)$ & \\
\hline & Sociocultural theory (ST) & $1(1.16)$ & \\
\hline & Theory of relationship quality (TRQ) & $1(1.16)$ & \\
\hline \multirow[t]{2}{*}{ Engagement/behavioral dimension } & Theory of planned behavior (TPB) & $4(6.66)$ & $6(10)$ \\
\hline & Theory of reasoned action (TRA) & $2(3.33)$ & \\
\hline \multirow[t]{5}{*}{ Others } & Marketing theory (MT) & $1(1.16)$ & $4(6.66)$ \\
\hline & Implicit theory of intelligence (ITI) & $1(1.16)$ & \\
\hline & Herzberg's (1968) two factor theory (HTFT) & $1(1.16)$ & \\
\hline & Rogers's innovation-diffusion theory (RIDT) & $1(1.16)$ & \\
\hline & Total & $60(100)$ & $60(100)$ \\
\hline
\end{tabular}

and pedagogical dimensions of MOOCs. This classification concurs with Piccoli et al's (2001) conceptualization of a technology-based learning environment such as MOOCs as an entirety with learner's control, behavioral, social, technological, and pedagogical dimensions. These dimensions are further explained in the following section.

Learner's control dimension encompasses theories emphasize the learners and their abilities to learn from MOOCs in a self-directed way. This dimension includes SDT, PRT, SRLT and CVTAE, all of which pay special attention to the learner as an active learning agent in MOOCs. Theories covered by the pedagogical dimension are more about the pedagogical, teaching and learning aspects of MOOCs. This dimension includes EVT, AGT, ECT, CLT, ALT and ELT. Theories in this dimension are about how to create a constructive learning environment in MOOCs, learning expectation and achievement in MOOCs and the implications of learning concepts to hold and sustain MOOC-based learning (Kesim \& Altınpulluk, 2015). Technology-based theories are about embracing new technologies and technological features and using them in MOOCs to benefit learning at scale (Khan et al., 2018). This dimension includes TAM, FT, TTAT, MRT and TNE, which are related to the acceptance of technology and the application of networks and media in education (Wu \& Chen, 2017). Theories encompassed by the social dimension, namely CT, SCT, ST and TRQ, address social interactions and co-learning dynamics 
and activities happening in MOOCs (Barak et al, 2016; Sun et al, 2019). Engagement/ behavioral theories are mainly used to predict how individuals will behave based on their pre-existing attitudes and behavioral intentions (Maya-Jariego et al., 2020). This dimension includes TPB and TRA theories which explain the relationship between attitudes and behaviors within human action (Sheppard et al., 1988). The others dimension also includes four theories of MT, ITI, HTFT, and RIDT.

Since our review revealed that SDT is the most commonly used theory among all those theories, and considerable number of the included publications underpinned their research on SDT, therefore, we decided to focus in this theory and further explain its relation with MOOCs' retention.

Self-determination theory (SDT): This theory explicates reasons for human behavior occurrence (Abdullatif \& Velázquez-Iturbide, 2020). According to SDT, three factors including autonomy (need for having choice and control), competence (need for being effective), and relatedness (need for connecting with others) explain why and how a certain human behavior occurs (Deci \& Ryan, 2012). In MOOCs, participants can see, choose, register for any course they want, and follow a course at their pace (Khan et al., 2018). It implies the positive role of MOOCs in reinforcing a sense of freedom and autonomy. Zhou (2016) found that autonomous motivation has a significant impact on MOOCs participants' decisions. In another study, Khan et al. (2018) reported that learners' intention to use MOOCs is positively influenced by perceived autonomy. Buhr et al. (2019) also confirmed that autonomy in MOOCs leads to a decrease in boredom and increase in enjoyment. Sense of competence results in the feeling of being effective and capable which empowers participants to put more effort into MOOCs (Khan et al, 2018). MOOCs offers opportunities for participants to learn, find values, and express their abilities (Hew \& Kadir, 2017). This indicates that there is a relationship between perceived sense of competence and MOOCs use. To complete this section, we can say that given that learning in the MOOCs is voluntary and self-regulating, the role of 'self' in this learning environment is important (Martinez-Lopez et al., 2017); The SDT is more related to the self-regulatory learning environment. Also, SDT's main components, namely, autonomy (i.e., the need for having choice and control), competence, and relatedness, lend themselves best to the specifications of MOOCs as open, self-directed, social, and Tech-based learning environments (Khan et al., 2018).

Studies showed that perceived competence is correlated with involvement and behavioral intention to use MOOCs (Hew \& Kadir, 2016; Khan et al., 2018). The desire to interact with others and the feeling of being connected strengthen a sense of belonging which could help learners to engage more with other learners (Khan et al., 2018). This implies the importance of relatedness as a social motive. Khan et al. (2018) study showed that relatedness has a positive impact on participants' MOOCs adoption. A study by Buhr et al. (2019) showed that enjoyment in MOOCs is positively influenced by relatedness while boredom in MOOCs was decreased by relatedness. Joo et al. (2018) reported that SDT has an impact on MOOCs participants' satisfaction which is correlated with continuance intention to use MOOCs. In another study, Sun et al. (2019) pointed out that SDT can positively support psychological and behavioral engagement in MOOCs. In SDT theory, autonomy, competence, and relatedness have flowed between external and internal motivations. The more learners' autonomy, competence, and relatedness 
motivation are internal, the more they tend to be self-determined and vice versa (Joo et al., 2018). Based on the above explanation, in Fig. 3 an overview of SDT role concerning support MOOCs completion was presented.

\section{Research Question 3}

To what extent does motivation support participants' course completion in MOOCs?

A concept map provided in Fig. 4 illustrates that MOOCs' completion is influenced by motivational factors in two ways. First, motivational factors could straightly stimulate MOOCs' participants to complete a course. In this regard, a review of included publications showed that all six main motivational types could directly motivate users to finish MOOCs. Second, six educational features were identified to play a mediating role in the relationship between motivation and MOOCs completion including satisfaction, selfregulation, attitude toward using MOOC, performance, engagement, and participation (Fig. 4 shows an oval). For example, this concept map showed that academic motives with the mediating role of satisfaction, self-regulation and, engagement, it has a significant effect on the MOOC completion rate. Course and professional motives can be effective in completing MOOCs by mediating the role of satisfaction and engagement. The results also showed that social motives positively affected participants' engagement, performance, and participation, and these educational features were meaningfully correlated with MOOCs completion. Personal motives with mediating role of engagement, satisfaction, and participation affect the rate of completion of MOOCs. And finally, technological motives and professional motives influenced participants' attitudes toward using MOOCs which was meaningfully correlated with MOOCs' completion. The concept map also illustrated that there was a relationship among motivational types.

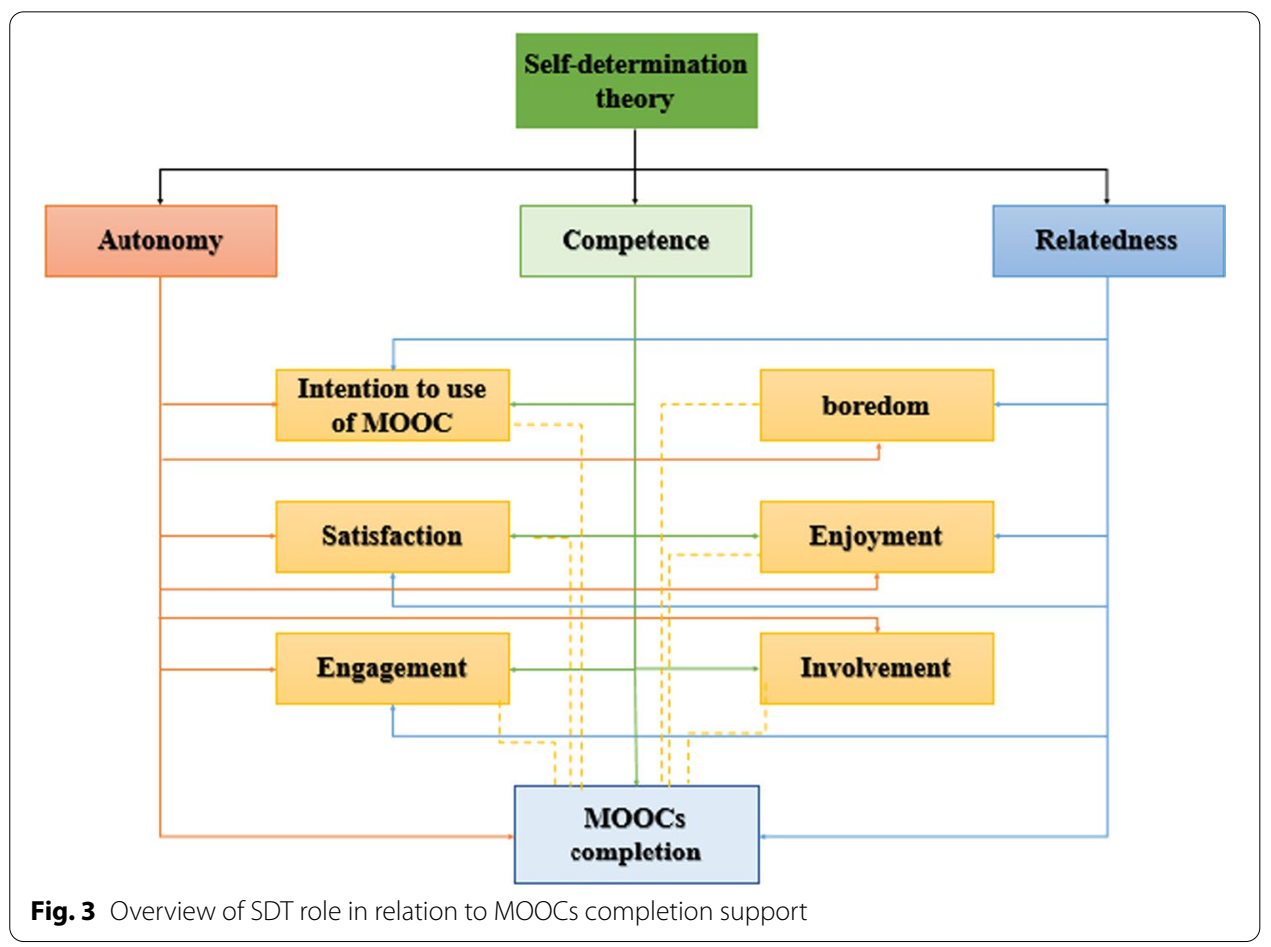




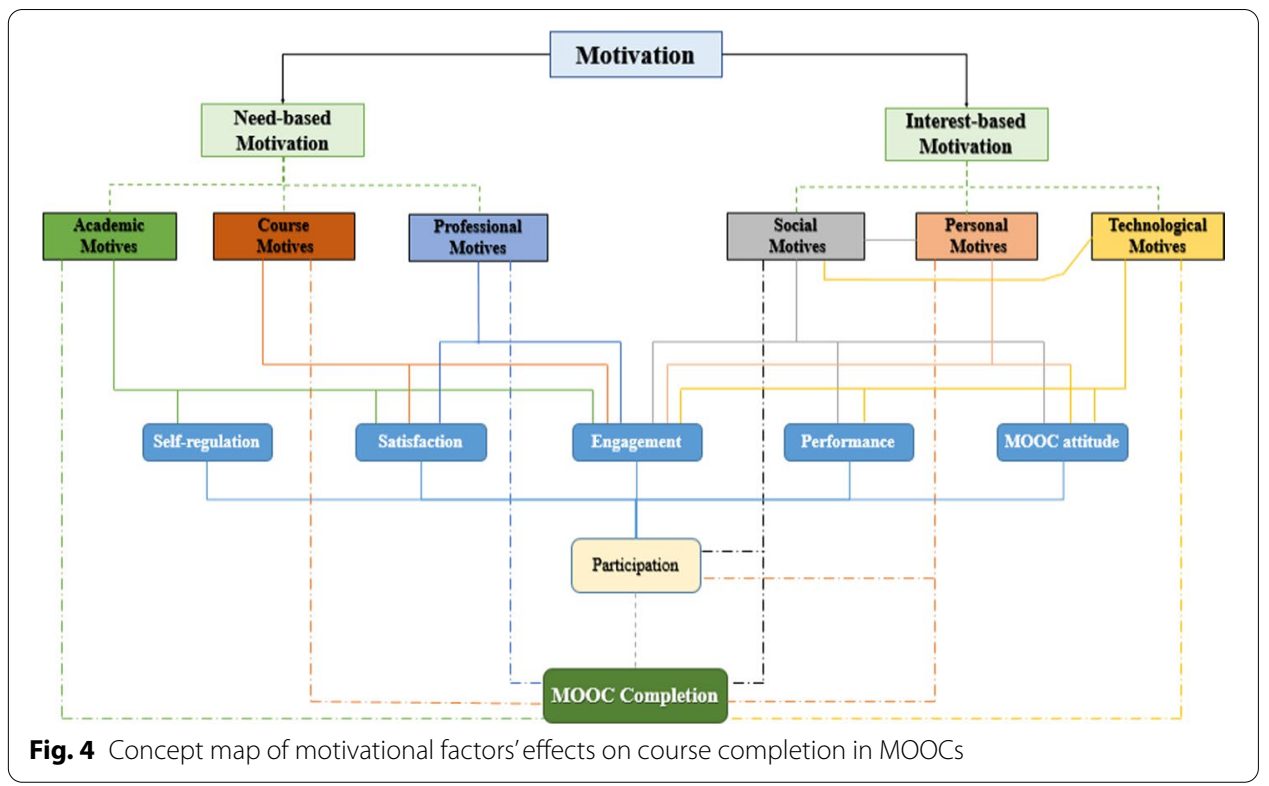

As shown in Fig. 4, social motives could influence participants' personal motives, and also technological motives could affect users' social motives. That is to say that personal motives had a mediating role between participants' social motives and MOOCS completion and social motives had a mediating role between participants technological motives and MOOCS completion.

\section{Discussion}

This systematic review was conducted to give an explanation of how motivational types and theories influence participants' retention rates for MOOCs, and how these motivational factors could support MOOCs users' persistence. To meet the target of this study, 50 scientific publications were analyzed and results were described in both quantitative and qualitative formats. Results showed that $56 \%$ of selected papers were published between 2018 and 2020 and in total 46\% of reviewed papers were published in highlyranked journals. This finding might be an indication of the importance of this topic in the field of educational technology. Results also showed that more than half of studies (64\%) adopted quantitative research methods, while only $16 \%$ and $20 \%$ of studies used qualitative and mixed research methods. It was also found that Coursera and edX were the most popular platforms in reviewed publications while survey methods were the most used data collection tool with quantitative and descriptive statistical tools. These findings suggest that easy access to Coursera and edX courses provide opportunities for more quantitative research compared to other research methods.

Data analysis and categorization showed that academic, course, professional, personal, social and technological motives are the six major factors impacting learner retention rates in MOOCs. These six categories were classified into two motivational sources: need-based and interest-based. The findings of this study can be supported by previous studies. For example, Aldowah et al. (2020), Sun et al. (2019), Khan et al. (2018), Shao (2018), Uchidiuno et al. (2018), Bayeck (2016), and Xiong et al. (2015) confirmed that 
social motivations such as connecting with others, relatedness, friends taking a course, and social norms impact users' retention in MOOC. Furthermore, other studies such as Sun et al. (2019), Bonk and Lee (2017), Uchidiuno et al. (2018), Bayeck (2016), Salmon et al. (2017), and Petronzi and Hadi (2016) highlighted the importance of professional motivations such as relevancy to job, acquiring a new skill, and professional development as motivational reasons to complete MOOCs. These findings indicate that learners participate in MOOCs with diverse motivational backgrounds ranging from academic to professional. These findings provide practical information for MOOC designers and developers. This indicates that not only academic reasons for MOOCs participation and completion is highly crucial, but also other important motivational types could considerably influence user decisions to drop out of MOOCs or to complete them.

The review of included publications revealed that SDT is the most commonly used theory to support MOOC user motivation for course completion. Respectively, followed by the technology acceptance model and the theory of planned behavior as ranked in the second and third place. In this study, we also explained in depth SDT and presented a concept map of the three principles of SDT's role in MOOC completion based on the data collected from reviewed publications. This concept map showed that three universal psychological needs including autonomy, competence, and relatedness play a direct motivational role in MOOCs' completion; however, they can also indirectly affect retention in MOOCs through influencing intention, boredom, satisfaction, enjoyment, engagement, and involvement of participants. The findings of this study clarify how SDT as a motivational theory could support MOOCs' completion. These findings are in line with some prior studies (e.g., Buhr et al., 2019; Joo et al., 2018; Khan et al., 2018; Sun et al., 2019).

We also provided a concept map to explore how different motivation factors support course completion in MOOCs. The results showed that in general, motivational factors played a twofold role in relation to MOOCs. First, reviewed publications suggested that motivational types such as personal motivations (e.g., curiosity, personal growth, selfenjoyment, etc.) and professional motivations (e.g., relevancy to job, perceived usefulness, fulfillment of the need for competence, etc.) could simply encourage participants to not drop out MOOCs. Second, included publications proposed that motivational factors influenced other educational practices such as engagement, performance, satisfaction, and self-regulation which are other key features to prevent MOOCs dropout. These findings can be supported by reviewed publications in this study such as Abdullatif and Velázquez-Iturbide (2020), Zhao et al. (2020), Sun et al. (2019), Khan et al. (2018), Watted and Barak (2018), Shao (2018), Shapiro et al. (2017), and Bayeck (2016). These findings provide insights for MOOCS designers and instructors to understand what motivational factors and to what extent can encourage learners to finish MOOC.

\section{Conclusion}

Previous studies merely focused on a particular aspect of motivation concerning user's persistence in MOOCs, while this systematic literature review covered the most recent publications in this regard to shed light on the role of motivation in MOOC retention rates. This study bridged motivation to retention in MOOCs with a specific focus on motivational factors and theories and also mapped how motivation supports 
MOOC retention rates. Although, in reviewed publications, it was reported that there is a meaningful relationship between participants' motivation and $\mathrm{MOOC}$ retention rates, none of them exclusively provided a comprehensive overview of motivational factors and theories which influence MOOC retention rates. The results of this study led to practical information for MOOCs' designers on what factors and how these factors motivate MOOCs' users to complete a course. The scanning of included publications showed that motivational factors could affect MOOCs' completion both directly and indirectly. This finding implies that MOOC designers should consider motivation as a key element of any MOOCs' development.

Although this study presented a conceptual link between motivation and retention rates for MOOCs, there is a concern regarding its generalizability since we only covered English peer-reviewed publications from 2015 to 2020 and it is possible to miss other relevant studies. Further literature review studies are suggested to map the roles of motivation in $\mathrm{MOOC}$ retention rates concerning other inclusion and exclusion criteria. This study provided information on variation of MOOCs' completion motives. However, it was not clarified how motivation differs concerning kind of participants who took MOOCs. Further studies are recommended to clarify relationship between types of participants who completed MOOCs and their motivational reasons. This study mainly focused on what motivates participants to finish MOOCs and it did not provide any formation on how instructors' motivation could affect users' retention in MOOCs. It is suggested to conduct a systematic review on relationship between instructors' motivation and participants related to MOOC dropout rates. Furthermore, this study provided information on the role of motivational types in MOOCs' retention rates based on their frequency mentioned in included publications. Further mate-analysis studies required to show impacts of motivational factors on MOOCs' completion based on their effect size. Hew et al. (2020) pointed out that completion rates in MOOCs should not be defined as the only indication of MOOC success, since many users have no intention to finish MOOCs and they may focus more on specific sub-sets of a course. This implies that we should cautiously interpret findings of this study and not fall in a trap of considering findings as an implication for MOOC success. In conclusion, given the extent of the connections made among motivational factors, theories, mediating variables, and retention, it can be argued that the findings of this study can provide practical designs for further practices and future studies.

\section{Abbreviations}

MOOC: Massive open online course; SEM: Structural equation modeling; SDT: Self-determination theory; TAM: Technology acceptance model; TPB: Theory of planned behavior; EVT: Expectancy value theory; PRT: Psychological reactance theory; ECT: Expectation confirmation theory; AGT: Achievement goal theory; TRA: Theory of reasoned action.

\footnotetext{
Author information

Mehdi Badali is a Ph.D. graduate of in the field of Educational Technology from Tarbiat Modares University, Iran. His research interests include E-Learning, Massive Open Online Course (MOOCs), Active learning and Instructional Design. Javad Hatami is a professor in Educational Technology at Tarbiat Modares University, Iran. His research interests include Educational Development and Evaluation, E-Learning, Massive Open Online Course (MOOCs), Concept Map, Curriculum in Education, Teaching Methods, and Measurement and Assessment.

Seyyed Kazem Banihashem is a Ph.D. graduate in the field of Educational Technology from Allameh Tabataba'i University, Iran. He currently works as a postdoctoral researcher at Wageningen University and Research, the Netherlands. His research interests include Learning Analytics, Technology Enhanced Learning, Learning Theories, Learning Design, Peer Feedback, and Computer-Supported Collaborative Learning (CSCL).
} 
Ebrahim Rahimi is an assistant professor in Educational Technology at the Open University of the Netherlands. His research interests include Educational Technology, E-Learning, and Massive Open Online Course (MOOCs).

Omid Noroozi is an associate professor in Educational Technology at Education and Learning Sciences Group, Wageningen University and Research, the Netherlands. His research interests include Collaborative Learning, E-Learning, Computer-Supported Collaborative Learning (CSCL), Argumentative Knowledge Construction in CSCL, Argumentation Based CSCL, and CSCL Scripts.

Zahra Eslami is an assistant professor at Shahid Beheshti University of Medical Sciences, Tehran, Iran. Her research interests include Educational Development and Evaluation, and Measurement and Assessment.

\section{Acknowledgements}

None

\section{Authors' contributions}

$\mathrm{MB}$ and SKB collected data and wrote the manuscript. JH and ON helped with designing the study and analysis. EB and ZE read the manuscript, proofread it, and provided insightful comments on the manuscript. All authors read and approved the final manuscript.

\section{Funding}

There was no funding for this article.

\section{Availability of data and materials}

Data can be shared by the corresponding author upon reasonable request.

\section{Declarations}

\section{Competing interests}

There is no conflict of interests related to this article.

\section{Author details}

${ }^{1}$ Department of Education, Faculty of Humanities, Tarbiat Modares University, Tehran, Iran. ${ }^{2}$ Education and Learning Sciences Group, Faculty of Social Sciences, Wageningen University and Research, Wageningen, The Netherlands. ${ }^{3}$ Department of Computer Science, Faculty of Science, The Open University of the Netherlands, Heerlen, The Netherlands. ${ }^{4}$ Virtual School of Medical Education and Management, Shahid Beheshti University of Medical Sciences, Tehran, Iran.

Received: 17 April 2021 Accepted: 25 November 2021

Published online: 05 February 2022

\section{References}

Papers with asterisk $(*)$ were included in the systematic review.

Abdullatif, H., \& Velázquez-Iturbide, J. Á. (2020). Relationship between motivations, personality traits and intention to continue using MOOCs. Education and Information Technologies, 25(5), 4417-4435. https://doi.org/10.1007/ s10639-020-10161-z*

Ahl, H. (2008). Motivation theory as power in disguise. In Foucault and lifelong learning (pp. 171-183). Routledge. eBook: ISBN9780203933411

Alario-Hoyos, C., Estévez-Ayres, I., Pérez-Sanagustín, M., Kloos, C. D., \& Fernández-Panadero, C. (2017). Understanding learners' motivation and learning strategies in MOOCs. The International Review of Research in Open and Distributed Learning, 18(3), 119-137. https://doi.org/10.19173/irrodl.vs18i3.2996*

Aldowah, H., Al-Samarraie, H., Alzahrani, A. I., \& Alalwan, N. (2020). Factors affecting student dropout in MOOCs: A cause and effect decision-making model. Journal of Computing in Higher Education, 32, 1-26. https://doi.org/10.1007/ s12528-019-09241-y*

Alraimi, K. M., Zo, H., \& Ciganek, A. P. (2015). Understanding the MOOCs continuance: The role of openness and reputation. Computers \& Education, 80, 28-38. https://doi.org/10.1016/j.compedu.2014.08.006*

Badali, M., Hatami, J., Farrokhnia, M., \& Noroozi, O. (2020). The effects of using Merrill's first principles of instruction on learning and satisfaction in MOOC. Innovations in Education and Teaching International, 1-10.

Barak, M., Watted, A., \& Haick, H. (2016). Motivation to learn in massive open online courses: Examining aspects of language and social engagement. Computers \& Education, 94, 49-60. https://doi.org/10.1016/j.compedu.2015.11.010*

Bayeck, R. (2016). Exploratory study of MOOCS learners' demographics and motivation: The case of students involved in groups. Open Praxis, 8(3), 223-233. https://doi.org/10.5944/openpraxis.8.3.282*

Bonk, C. J., \& Lee, M. M. (2017). Motivations, achievements, and challenges of self-directed informal learners in open educational environments and MOOCs. Journal of Learning for Development, 4(1), 36-57.*

Buhr, E. E., Daniels, L. M., \& Goegan, L. D. (2019). Cognitive appraisals mediate relationships between two basic psychological needs and emotions in a massive open online course. Computers in Human Behavior, 96, 85-94. https://doi. org/10.1016/j.chb.2019.02.009*

Carrera, J., \& Ramírez-Hernández, D. (2018). Innovative education in MOOCS for sustainability: Learnings and motivations. Sustainability, 10(9), 2990. https://doi.org/10.3390/su10092990* 
Chang, R. I., Hung, Y. H., \& Lin, C. F. (2015). Survey of learning experiences and influence of learning style preferences on user intentions regarding MOOCS. British Journal of Educational Technology, 46(3), 528-541. https://doi.org/10.1111/ bjet.12275*

Charo, R., Maite, A. S., \& Guillermo, M. (2020). Self-regulation of learning and MOOCS retention. Computers in Human Behavior, 111, 106423. https://doi.org/10.1016/j.chb.2020.106423*

Dalipi, F., Imran, A. S., \& Kastrati, Z. (2018). MOOCS dropout prediction using machine learning techniques: Review and research challenges. In 2018 IEEE global engineering education conference (EDUCON) (pp. 1007-1014). IEEE. https:// doi.org/10.1109/EDUCON.2018.8363340.

Deci, E. L., \& Ryan, R. M. (2012). Self-determination theory. In P. A. M. Van Lange, A. W. Kruglanski, \& E. T. Higgins (Eds.), Handbook of theories of social psychology (pp. 416-436). Sage Publications Ltd. https://doi.org/10.4135/9781446249 215.n21

Deshpande, A., \& Chukhlomin, V. (2017). What makes a good MOOC: A field study of factors impacting student motivation to learn. American Journal of Distance Education, 31(4), 275-293. https://doi.org/10.1080/08923647.2017.13775 $13^{*}$

Doo, M. Y., Tang, Y., Bonk, C. J., \& Zhu, M. (2020). MOOCS instructor motivation and career development. Distance Education, 41(1), 26-47. https://doi.org/10.1080/01587919.2020.1724770*

El Said, G. R. (2017). Understanding how learners use massive open online courses and why they drop out: Thematic analysis of an interview study in a developing country. Journal of Educational Computing Research, 55(5), 724-752. https://doi.org/10.1177/0735633116681302*

Eriksson, T., Adawi, T., \& Stöhr, C. (2017). "Time is the bottleneck": A qualitative study exploring why learners drop out of MOOCs. Jounal of Computing in Higher Education, 29(1), 133-146. https://doi.org/10.1007/s12528-016-9127-8*

Godman, M. (2013). Why we do things together: The social motivation for joint action. Philosophical Psychology, 26(4), 588-603. https://doi.org/10.1080/09515089.2012.670905

Goopio, J., \& Cheung, C. (2020). The MOOCS dropout phenomenon and retention strategies. Journal of Teaching in Travel \& Tourism. https://doi.org/10.1080/15313220.2020.1809050

Green, P. I., Jr., Finkel, E. J., Fitzsimons, G. M., \& Gino, F. (2017). The energizing nature of work engagement: Toward a new need-based theory of work motivation. Research in Organizational Behavior, 37, 1-18. https://doi.org/10.1016/j.riob. 2017.10.007

Greene, J. A., Oswald, C. A., \& Pomerantz, J. (2015). Predictors of retention and achievement in a massive open online course. American Educational Research Journal, 52(5), 925-955. https://doi.org/10.3102/0002831215584621*

Gregori, E. B., Zhang, J., Galván-Fernández, C., \& de Asís Fernández-Navarro, F. (2018). Learner support in MOOCs: Identifying variables linked to completion. Computers \& Education, 122, 153-168. https://doi.org/10.1016/j.compedu.2018. $03.014^{*}$

Hew, K. F., Hu, X., Qiao, C., \& Tang, Y. (2020). What predicts student satisfaction with MOOCs: A gradient boosting trees supervised machine learning and sentiment analysis approach. Computers \& Education, 145, 103724. https://doi.org/ 10.1016/j.compedu.2019.103724

Hew, T. S., \& Kadir, S. L. S. A. (2016). Predicting the acceptance of cloud-based virtual learning environment: The roles of self-determination and channel expansion theory. Telematics and Informatics, 33(4), 990-1013. https://doi.org/10. 1016/j.tele.2016.01.004

Hew, T. S., \& Kadir, S. L. S. A. (2017). Applying channel expansion and self-determination theory in predicting use behaviour of cloud-based VLE. Behaviour \& Information Technology, 36(9), 875-896. https://doi.org/10.1080/0144929X.2017. 1307450

Hone, K. S., \& El Said, G. R. (2016). Exploring the factors affecting MOOCS retention: A survey study. Computers \& Education, 98, 157-168. https://doi.org/10.1016/j.compedu.2016.03.016*

James, J. L. (2020). Students as stakeholders: understanding expectations can increase student retention. Journal of College Student Retention: Research, Theory \& Practice. https://doi.org/10.1177/1521025119898844*

Joo, Y. J., So, H. J., \& Kim, N. H. (2018). Examination of relationships among students'self-determination, technology acceptance, satisfaction, and continuance intention to use K-MOOCs. Computers \& Education, 122, 260-272. https:// doi.org/10.1016/j.compedu.2018.01.003*

Jordan, K. (2014). Initial trends in enrollment and completion of Massive Open Online Courses. The International Review of Research in Open and Distance Learning, 15, 133-160. https://doi.org/10.19173/irrodl.v15i1.1651

Jung, Y., \& Lee, J. (2018). Learning engagement and persistence in massive open online courses (MOOCS). Computers \& Education, 122, 9-22. https://doi.org/10.1016/j.compedu.2018.02.013*

Kesim, M., \& Altınpulluk, H. (2015). A theoretical analysis of MOOCs types from a perspective of learning theories. Procedia-Social and Behavioral Sciences, 186, 15-19. https://doi.org/10.1016/j.sbspro.2015.04.056

Khan, I. U., Hameed, Z., Yu, Y., Islam, T., Sheikh, Z., \& Khan, S. U. (2018). Predicting the acceptance of MOOCs in a developing country: Application of task-technology fit model, social motivation, and self-determination theory. Telematics and Informatics, 35(4), 964-978. https://doi.org/10.1016/j.tele.2017.09.009*

Kim, T. D., Yang, M. Y., Bae, J., Min, B. A., Lee, I., \& Kim, J. (2017). Escape from infinite freedom: Effects of constraining user freedom on the prevention of dropout in an online learning context. Computers in Human Behavior, 66, 217-231. https://doi.org/10.1016/j.chb.2016.09.019*

Kizilcec, R. F., \& Halawa, S. (2015). Attrition and achievement gaps in online learning. In Proceedings of the Second ACM Conference on Learning @ Scale (pp. 57-66). New York: Association for Computing Machinery. https://doi.org/10. $1145 / 2724660.2724680$

Kyewski, E., \& Krämer, N. C. (2018). To gamify or not to gamify? An experimental field study of the influence of badges on motivation, activity, and performance in an online learning course. Computers \& Education, 118, 25-37. https://doi. org/10.1016/j.compedu.2017.11.006*

Liyanagunawardena, T. R., Adams, A. A., \& Williams, S. A. (2013). MOOCs: A systematic study of the published literature 2008-2012. International Review of Research in Open and Distributed Learning, 14, 202-227. https://doi.org/10.19173/ irrodl.v14i3.1455 
Lizcano, D., Lara, J. A., White, B., \& Aljawarneh, S. (2020). Blockchain-based approach to create a model of trust in open and ubiquitous higher education. Journal of Computing in Higher Education, 32(1), 109-134. https://doi.org/10.1007/ s12528-019-09209-y

Locke, K. D. (2015). Agentic and communal social motives. Social and Personality Psychology Compass, 9(10), 525-538. https://doi.org/10.1111/spc3.12201

Lockwood, C., \& Oh, E. G. (2017). Systematic reviews: Guidelines, tools, and checklists for authors. Nursing \& Health Sciences, 19(3), 273-277. https://doi.org/10.1111/nhs.12353

Lu, Y., Hu, X. M., Huang, X. L., Zhuang, X. D., Guo, P., Feng, L. F., Hu, W., Chen, L., Zou, H., \& Hao, Y. T. (2017). The relationship between job satisfaction, work stress, work-family conflict, and turnover intention among physicians in Guangdong, China: a cross-sectional study. BMJ Open, 7(5), e014894. https://doi.org/10.1136/bmjopen-2016-014894

Martinez-Lopez, R., Yot, C., Tuovila, I., \& Perera-Rodríguez, V. H. (2017). Online self-regulated learning questionnaire in a Russian MOOC. Computers in Human Behavior, 75, 966-974. https://doi.org/10.1016/j.chb.2017.06.015

Maya-Jariego, I., Holgado, D., González-Tinoco, E., Castaño-Muñoz, J., \& Punie, Y. (2020). Typology of motivation and learning intentions of users in MOOCs: The MOOCKNOWLEDGE study. Educational Technology Research and Development, 68(1), 203-224. https://doi.org/10.1007/s11423-019-09682-3*

Milligan, C., \& Littlejohn, A. (2017). Why study on a MOOC? The motives of students and professionals. International Review of Research in Open and Distributed Learning, 18(2), 92-102. https://doi.org/10.19173/irrodl.v18i2.3033

Narayanasamy, S. K., \& Elçi, A. (2020). An effective prediction model for online course dropout rate. International Journal of Distance Education Technologies (IJDET), 18(4), 94-110. https://doi.org/10.4018/IJDET.2020100106

Nurhudatiana, A., \& Caesarion, A. S. (2020). Exploring User Experience of Massive Open Online Courses (MOOCs) A Case Study of Millennial Learners in Jakarta, Indonesia. In Proceedings of the 9th international conference on educational and information technology (pp. 44-49). New York: Association for Computing Machinery. https://doi.org/10.1145/ 3383923.3383968

Ortega-Arranz, A., Bote-Lorenzo, M. L., Asensio-Pérez, J. I., Martínez-Monés, A., Gómez-Sánchez, E., \& Dimitriadis, Y. (2019). To reward and beyond: Analyzing the effect of reward-based strategies in a MOOC. Computers \& Education, 142, 103639. https://doi.org/10.1016/j.compedu.2019.103639*

Petronzi, D., \& Hadi, M. (2016). Exploring the factors associated with MOOCS engagement, retention and the wider benefits for learners. European Journal of Open, Distance and E-Learning, 19(2), 112-129. https://doi.org/10.1515/ eurodl-2016-0011*

Piccoli, G., Ahmad, R., \& Ives, B. (2001). Web-based virtual learning environments: A research framework and a preliminary assessment of effectiveness in basic IT skills training. MIS Quarterly. https://doi.org/10.2307/3250989

Salmon, G., Pechenkina, E., Chase, A. M., \& Ross, B. (2017). Designing massive open online courses to take account of participant motivations and expectations. British Journal of Educational Technology, 48(6), 1284-1294. https://doi. org/10.1111/bjet.12497*

Scheel, M., Madabhushi, S., \& Backhaus, A. (2009). The academic motivation of at-risk students in a counseling prevention program. Counseling Psychologist, 37(8), 1147-1178. https://doi.org/10.1177/0011000009338495

Shao, Z. (2018). Examining the impact mechanism of social psychological motivations on individuals' continuance intention of MOOCs. Internet Research. https://doi.org/10.1108/IntR-11-2016-0335*

Shapiro, H. B., Lee, C. H., Roth, N. E. W., Li, K., Çetinkaya-Rundel, M., \& Canelas, D. A. (2017). Understanding the massive open online course (MOOC) student experience: An examination of attitudes, motivations, and barriers. Computers \& Education, 110, 35-50. https://doi.org/10.1016/j.compedu.2017.03.003*

Shen, B., Chen, A., Tolley, H., \& Scrabis, K. A. (2003). Gender and interest-based motivation in learning dance. Journal of Teaching in Physical Education, 22(4), 396-409. https://doi.org/10.1123/jtpe.22.4.396

Sheppard, B. H., Hartwick, J., \& Warshaw, P. R. (1988). The theory of reasoned action: A meta-analysis of past research with recommendations for modifications and future research. Journal of Consumer Research, 15(3), 325-343. https://doi. org/10.1086/209170

Sun, Y., Ni, L., Zhao, Y., Shen, X. L., \& Wang, N. (2019). Understanding students' engagement in MOOCs: An integration of self-determination theory and theory of relationship quality. British Journal of Educational Technology, 50(6), 3156-3174. https://doi.org/10.1111/bjet.12724*

Tang, C. M., \& Chaw, L. (2019). Driving high inclination to complete massive open online courses (MOOCs): motivation and engagement factors for learners. Electronic Journal of e-Learning, 17, 118-130. https://doi.org/10.34190/JEL.17.2. $05^{*}$

Tsai, Y. H., Lin, C. H., Hong, J. C., \& Tai, K. H. (2018). The effects of metacognition on online learning interest and continuance to learn with MOOCs. Computers \& Education, 121, 18-29. https://doi.org/10.1016/j.compedu.2018.02.011*

Uchidiuno, J. O., Ogan, A., Yarzebinski, E., \& Hammer, J. (2018). Going global: Understanding English language learners' student motivation in English-language MOOCs. International Journal of Artificial Intelligence in Education, 28(4), 528-552. https://doi.org/10.1007/s40593-017-0159-7*

Verbert, K., Manouselis, N., Ochoa, X., Wolpers, M., Drachsler, H., Bosnic, I., \& Duval, E. (2012). Context-aware recommender systems for learning: A survey and future challenges. IEEE Transactions on Learning Technologies, 5(4), 318-335. https://doi.org/10.1109/TLT.2012.11

Wang, Y., \& Baker, R. (2015). Content or platform: Why do students complete MOOCs? Journal of Online Learning and Teaching, 11(1), 17. https://doi.org/10.19173/irrodl.v19i3.3393*

Wang, Y., \& Baker, R. (2018). Grit and intention: Why do learner's complete MOOCs? The International Review of Research in Open and Distributed Learning, 19(3), 20-42. https://doi.org/10.19173/irrodl.v19i3.3393*

Watted, A., \& Barak, M. (2018). Motivating factors of MOOCS completers: Comparing between university-affiliated students and general participants. The Internet and Higher Education, 37, 11-20. https://doi.org/10.1016/j.iheduc.2017. $12.001^{*}$

Welsh, D. H., \& Dragusin, M. (2013). The new generation of massive open online course (MOOCS) and entrepreneurship education. Small Business Institute Journal, 9(1), 51-65. 
Wu, B., \& Chen, X. (2017). Continuance intention to use MOOCs: Integrating the technology acceptance model (TAM) and task technology fit (TTF) model. Computers in Human Behavior, 67, 221-232. https://doi.org/10.1016/j.chb.2016.10. $028^{*}$

Xing, W., \& Du, D. (2019). Dropout prediction in MOOCs: Using deep learning for personalized intervention. Journal of Educational Computing Research, 57(3), 547-570. https://doi.org/10.1177/0735633118757015

Xiong, Y., Li, H., Kornhaber, M. L., Suen, H. K., Pursel, B., \& Goins, D. D. (2015). Examining the relations among student motivation, engagement, and retention in a MOOC: A structural equation modeling approach. Global Education Review, 2(3), 23-33.*

Zhao, Y., Wang, A., \& Sun, Y. (2020). Technological environment, virtual experience, and MOOCS continuance: A stimulusorganism-response perspective. Computers \& Education, 144, 103721. https://doi.org/10.1016/j.compedu.2019. $103721^{*}$

Zhou, M. (2016). Chinese university students' acceptance of MOOCs: A self-determination perspective. Computers \& Education, 92, 194-203. https://doi.org/10.1016/j.compedu.2015.10.012

Zhu, M., Sari, A., \& Lee, M. M. (2018). A systematic review of research methods and topics of the empirical MOOCS literature (2014-2016). The Internet and Higher Education, 37, 31-39.

Zhu, M., Sari, A., \& Lee, M. M. (2020). A comprehensive systematic review of MOOC research: Research techniques, topics, and trends from 2009 to 2019. Educational Technology Research and Development, 68, 1685-1710. https://doi.org/10. 1007/s11423-020-09798-x

Zimmerman, B. J. (2008). Investigating self-regulation and motivation: Historical background, methodological developments, and future prospects. American Educational Research Journal, 45, 166-183. https://doi.org/10.3102/00028 31207312909

\section{Publisher's Note}

Springer Nature remains neutral with regard to jurisdictional claims in published maps and institutional affiliations.

\section{Submit your manuscript to a SpringerOpen ${ }^{\circ}$ journal and benefit from:}

- Convenient online submission

- Rigorous peer review

- Open access: articles freely available online

- High visibility within the field

- Retaining the copyright to your article

Submit your next manuscript at $\gg$ springeropen.com 